University of Nebraska - Lincoln

DigitalCommons@University of Nebraska - Lincoln

Faculty Publications from the Harold W. Manter Laboratory of Parasitology

$6-1948$

\title{
A Contribution to the Study of Certain Avian Strigeids (Trematoda)
}

Asa C. Chandler

Rice Institute, Houston, Texas

Robert L. Rausch

University of Wisconsin - Madison, rausch@u.washington.edu

Follow this and additional works at: https://digitalcommons.unl.edu/parasitologyfacpubs

Part of the Parasitology Commons

Chandler, Asa C. and Rausch, Robert L., "A Contribution to the Study of Certain Avian Strigeids (Trematoda)" (1948). Faculty Publications from the Harold W. Manter Laboratory of Parasitology. 571. https://digitalcommons.unl.edu/parasitologyfacpubs/571

This Article is brought to you for free and open access by the Parasitology, Harold W. Manter Laboratory of at DigitalCommons@University of Nebraska - Lincoln. It has been accepted for inclusion in Faculty Publications from the Harold W. Manter Laboratory of Parasitology by an authorized administrator of DigitalCommons@University of Nebraska - Lincoln. 


\section{A CONTRIBUTION TO THE STUDY OF CERTAIN AVIAN STRIGEIDS (TREMATODA)}

\section{Asa C. Chandler and Robert Rausch*}

The examination of more than 200 species of birds by one of us (R.R.) during the past few years, has disclosed a number of interesting strigeids, some of which are considered in the present paper. Three species appear to be undescribed and two of these are of particular interest in that they occur in passeriform birds, a group rarely parasitized by strigeids. In addition to the descriptions of the new species, remarks concerning Hysteromorpha triloba (Rud. 1819) are included.

\section{Diplostomum crassum n. sp.}

(Fig. 3)

Diagnosis: Body 1.38 to $1.5 \mathrm{~mm}$ long. Forebody short and thick, bent dorsally, and measuring about 0.35 to $0.5 \mathrm{~mm}$ along the dorsal side, and 0.55 to $0.8 \mathrm{~mm}$ along the ventral side, with a dorso-ventral diameter of 375 to $520 \mu$. Hindbody $835 \mu$ to $1.0 \mathrm{~mm}$ long, with a dorso-ventral diameter of 44 to $58 \mu$. Oral sucker 85 to $100 \mu$ in diameter, and $85 \mu$ long, flanked by two deep pseudosuckers. Pharynx smaller, about 75 to $80 \mu$ in diameter, and $85 \mu$ long. Ventral sucker not seen, presumably concealed under the dense vitellaria in forebody. Holdfast organ, as seen in lateral view, thick, tongue-like, and about $290 \mu$ long; its anterior border situated about $285 \mu$ from anterior end. Ovary situated just behind junction of forebody with hindbody, measuring 70 to $100 \mu$ in length, and 160 to $175 \mu$ dorso-ventrally. Anterior testis situated just behind ovary, 200 to $235 \mu$ long, and 250 to $285 \mu$ dorso-ventrally. Posterior testis, as seen in lateral view, slightly overlapping anterior one and the larger of the two, measuring 220 to $330 \mu$ in length, and 310 to $350 \mu$ dorso-ventrally. Posterior border of hind testis 240 to $316 \mu$ from posterior end of body. Vitellaria very dense in forebody, extending forward almost to pharynx, but not entering holdfast organ; in hindbody, dense follicles extend to near posterior end of body, ventral to reproductive glands. Eggs up to about 25 in number, found throughout length of hindbody; they measure 100 to $105 \mu$ by 61 to $63 \mu$.

Host: Quiscalus versicolor Vieill. (bronze grackle).

Habitat: Small intestine.

Locality: Near Garland, Manitoba; collected September 5, 1947.

Type: U. S. Nat. Mus. Helm. Coll. No. 46340.

This species differs markedly from other members of the genus Diplostomum in the thickness of the forebody, which gives it more the appearance of a Strigea. Unfortunately, only three specimens, taken from a single host, were available for study; all were mounted laterally, or nearly so. The study of a large series of specimens, with sections, may make it necessary to erect a new genus for this peculiar parasite. It is the only member of the genus Diplostomum to be recorded from a passeriform bird.

\section{Uvulifer erraticus n. sp.}

(Fig. 1)

Diagnosis: Body 1.08 to $1.55 \mathrm{~mm}$ long. Forebody thin, curved ventrally at posterior end, 415 to $462 \mu$ long, and 164 to $193 \mu$ broad. Hindbody club-shaped, $638 \mu$ to $1.1 \mathrm{~mm}$ long, very narrow $(62$ to $110 \mu$ ) at region of attachment to forebody ; maximum diameter 193 to $264 \mu$. Oral sucker shallow, saucer-shaped, with margin unevenly curled backward; diameter 97 to $110 \mu$, and length only 24 to $35 \mu$. Pharynx immediately behind the oral sucker, about $45 \mu$ in diameter. Ventral sucker apparently absent, or very inconspicuous. Holdfast organ in posterior third of forebody, about 88 to $90 \mu$ long; approximately round, or slightly oval. Ovary round, situated

Received for publication, February 6, 1948.

* Contribution from the Biological Laboratory, Rice Institute, Houston, Texas, and the Department of Veterinary Science, University of Wisconsin, Madison, Wisconsin. 
about $2 / 5$ to $1 / 3$ length of hindbody behind the junction with forebody; 70 to $77 \mu$ in diameter. Testes tandem, immediately behind ovary in dorsal part of body; all three contiguous. Testes round or slightly deeper dorso-ventrally; about 150 to $160 \mu$ in diameter. Vitellaria scattered throughout posterior portion of hindbody, extending forward to a point slightly anterior to ovary. Genital cone protrusible, showing a bulb-like terminal expansion in one specimen. Eggs few, a maximum of three seen in a single specimen; 96 to $103 \mu$ by 58 to $61 \mu$.

Host: Toxostoma rufum (L.) (brown thrasher).

Habitat: Small intestine.

Locality: Greenville, Ohio; collected April 21, 1945.

Type: U. S. Nat. Mus. Helm. Coll. No. 46341.

Since, in the specimens available, it is not possible to determine whether a "genital bulb" is present in the ventral wall of the bursa, the characteristic feature distinguishing the genus Uvulifer from Pseudodiplostomum, this species can only be tentatively placed in the former genus. It resembles species in the genus Uvulifer more than those in Pseudodiplostomum in the broad oral sucker, seen less conspicuously in $U$. prosocotyle (Lutz), and in U. gracilis Yamaguti, and in the poor development of the ventral sucker. A discussion of the "genital bulb" in the genus Uvulifer is given by Dubois and Rausch (1948).

Seven specimens of this parasite were obtained, all from a single bird. This host also harboured 4 specimens of Plagiorhynchus formosus Van Cleave, 1918.

The occurrence of this species in a passeriform bird is very unusual, since all other members of the genera Uvulifer and Pseudodiplostomum are found in kingfishers.

\section{Neogogatea pandionis n. sp.}

(Fig. 2)

Diagnosis: Length 1.00 to $1.47 \mathrm{~mm}$. Forebody not sharply demarcated from the hindbody. Anterior part of body, to anterior border of holdfast organ, thin, slightly rolled ventrally at sides, and 350 to $570 \mu$ long by 190 to $255 \mu$ wide. Posterior portion of body approximately as wide as deep, constricted posteriorly into a narrow, truncated cone; maximum diameter 200 to $286 \mu$; cone 34 to $58 \mu$ in diameter, and 60 to $150 \mu$ long. Oral sucker not distinct in specimens at hand, obviously very small and poorly developed. Pharynx larger, 42 to $52 \mu$ in diameter, its anterior border only about $25 \mu$ from anterior end. Ventral sucker absent. Holdfast organ large and elongate, nearly as wide as body; posterior end not clearly defined.

Sex glands obscured by vitellaria in most specimens. Ovary small, about $66 \mu$ in diameter, situated at one side of posterior portion of anterior testis. Testes longer than wide, and apparently about as deep as wide; length of anterior testis 110 to $120 \mu$ long, and 75 to $96 \mu$ deep. Posterior testis larger, about $120 \mu$ in each direction in one specimen, and $167 \mu$ wide and $105 \mu$ long in another. Vitelline follicles large, confined to holdfast organ anteriorly, but extending beyond it posteriorly on either side, ventrally, to about level of middle of posterior testis. Cirrus pouch elongated; its proximal portion enlarged into a cylindrical, thin-walled seminal vesicle 155 to $175 \mu$ long, then narrowing to an ill-defined tube in posterior part of body, about 88 to $130 \mu$ long. Eggs 95 to $115 \mu$ long, and 58 to $73 \mu$ broad.

Host: Pandion haliaëtus carolinensis (Gm.) (osprey).

Habitat: Small intestine.

Locality: Waushara County, Wisconsin; collected April 13, 1947.

Type: U. S. Nat. Mus. Helm. Coll. No. 46342.

Two hundred and fifty-four specimens of this strigeid were obtained, along with 129 specimens of Nematostrigea serpens (Nitzsch), all from a single host.

The genus Neogogatea was established by Chandler and Rausch (1947) for a Cyathocotylid found in Bubo v. virginianus (Gm.). This second species possesses all the generic characters as given, but differs markedly in its smaller size, more elongate body, less obvious oral sucker, and smaller pharynx. 
Hysteromorpha triloba (Rud. 1819)

(Figs. 4 and 5)

When we attempted to identify strigeids from the double-crested cormorant, Phalacrocorax a. auritus (Less.), it was found that they agreed in most respects with the published descriptions of Hysteromorpha triloba (Rud.), but differed in regard to the holdfast organ. This organ apparently has not been well described in the published descriptions. Through the kindness of Dr. Gustav Swanson, we were able to obtain the unpublished master's thesis of Hawkins (1932), in which the holdfast organ of $H$. triloba has been correctly figured.

This organ is described by Hawkins as follows: "The contracted state of the holdfast is very variable. In an extended condition it is funnel-shaped, measuring approximately $0.430 \mathrm{~mm}$ in diameter. In a contracted state the most prominent feature is the median furrow; the holdfast proper appearing as a thickening of the surrounding tissue." The appearance of the holdfast organ is shown in figures 4 and 5 of the present paper. The trilobed appearance of the anterior edge of this structure appears to be characteristic.

This strigeid appears to be a common parasite of the double-crested cormorant. A total of 1,602 specimens was taken from a bird collected at Horicon Marsh, Wisconsin, and infected cormorants were also collected at Delta, Manitoba.

A slide of our specimens has been deposited in the U. S. Nat. Mus. Helm. Coll., slide number 46343.

\section{REFERENCES}

Chandler, A. C. AND RAusch, R. 1947 A study of strigeids from owls in north central United States. Trans. Am. Micr. Soc. 66: 283-292.

Durois, G. 1938 Monographie des Strigeida (Trematoda). Mem. Soc. neuchât. Sci. nat. 6: $1-535$.

And Rausch, R. 1948 A contribution to the study of North American strigeids (Trematoda). Amer. Midl. Nat. (in press).

Hawkins, B. L. 1932 A study of the genus Diplostomum von Nordmann of the trematode family Alariidae. Unpublished master's thesis, University of Minnesota.

\section{Explanation of Plate}

FIG. 1. Uvulifer erraticus n. sp., from Toxostoma rufum (L.).

FIG. 2. Neogogatea pandionis n. sp., from Pandion haliä̈tus carolinensis (Gm.). Ventral view.

FIG. 3. Diplostomum crassum n. sp., from Quiscalus versicolor Vieill. view.

Fig. 4. Hysteromorpha triloba (Rud.), from Phalacrocorax a. auritus (Less.). Ventral

FIG. 5. Hysteromorpha triloba (Rud.), lateral view 
Chandler \& Rausch in Journal of Parasitology (June 1948) v. 43, no. 1 (June 1948).

Copyright 1948, American Society of Parasitologists. Used by permission.
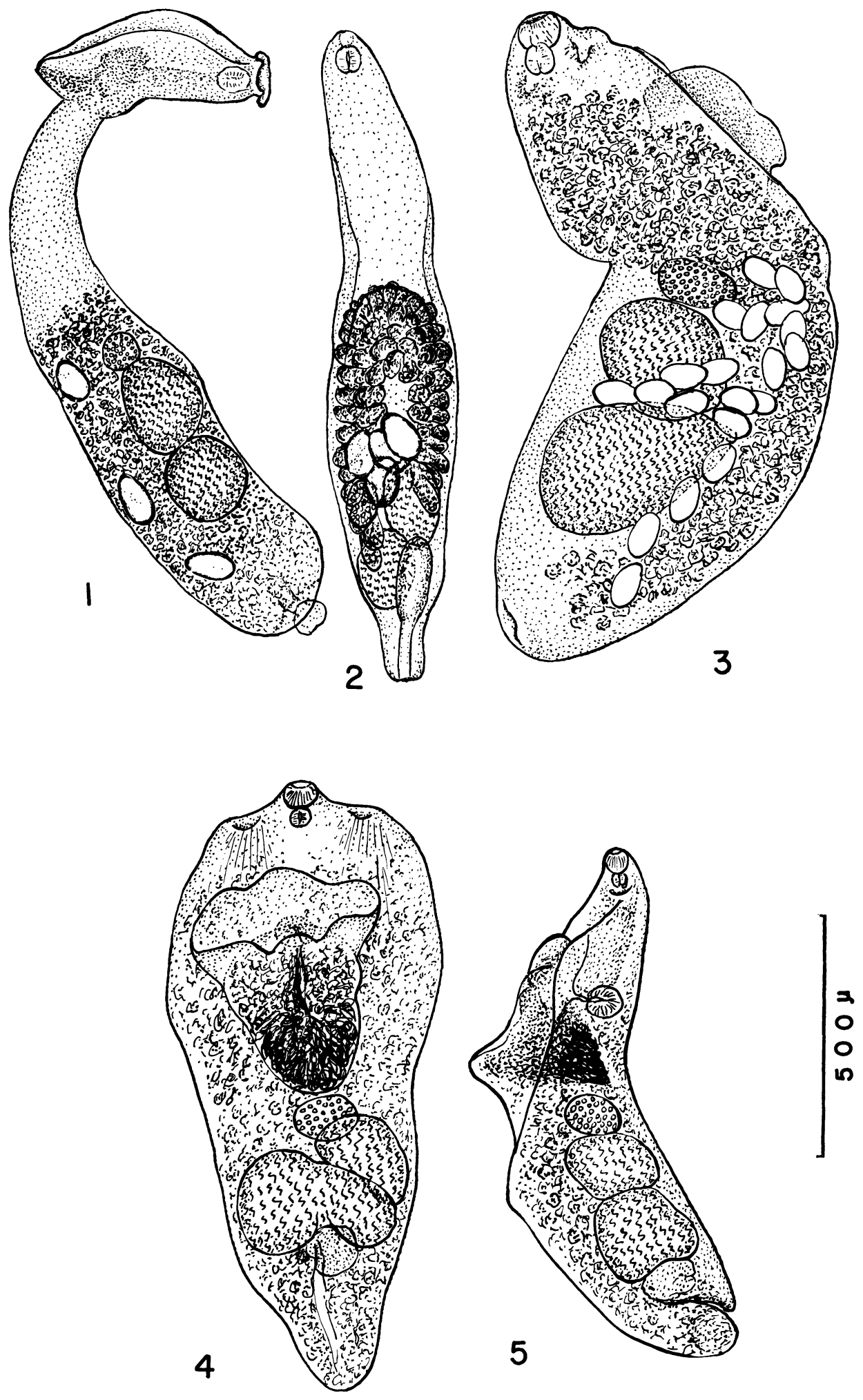